\title{
CEsifo \\ WORKING

\section{The Employment Effect of Inward FDI in China: What Do We Learn from the History?}

Hao Wang, Yuemei Ji, Qi Luo 


\section{Impressum:}

CESifo Working Papers

ISSN 2364-1428 (electronic version)

Publisher and distributor: Munich Society for the Promotion of Economic Research - CESifo

$\mathrm{GmbH}$

The international platform of Ludwigs-Maximilians University's Center for Economic Studies and the ifo Institute

Poschingerstr. 5, 81679 Munich, Germany

Telephone +49 (0)89 2180-2740, Telefax+49 (0)89 2180-17845, email office@cesifo.de

Editor: Clemens Fuest

https://www.cesifo.org/en/wp

An electronic version of the paper may be downloaded

- from the SSRN website: www.SSRN.com

- from the RePEc website: $\quad$ www.RePEc.org

- from the CESifo website: https://www.cesifo.org/en/wp 


\title{
The Employment Effect of Inward FDI in China: What Do We Learn from the History?
}

\begin{abstract}
This study investigates the long-term influence of colonial legacy on the nexus between inward foreign direct investment (FDI) and labor market. We construct a panel dataset containing 285 Chinese cities 2011 to 2017 along with detailed information about Chinese modern history during 1842-1955). Our results show that the inward FDI has a positive effect on employment and such an effect is more pronounced in the regions with colonial influence than their counterparts. Further, we find that the experience of Western colonization strengthens the positive effect of inward FDI on employment whereas the experience of Japanese colonization weakens or even overturns this positive effect. These findings are robust to controlling for the endogeneity between inward FDI and employment as well as employing alternative measures for the colonization.
\end{abstract}

JEL-Codes: N010, F210, J230.

Keywords: colonial legacy, foreign direct investment, employment, Chinese modern history.

Hao Wang

School of Slavonic and East European Studies

University College London

United Kingdom - Bloomsbury, WC1H OBW

hao-wang@ucl.ac.uk
Yuemei $\mathrm{Ji}^{*}$

School of Slavonic and East European Studies

University College London

United Kingdom - Bloomsbury, WC1H OBW

yuemei.ji@ucl.ac.uk

Qi Luo

School of Economics

Guangdong University of Finance and Economics

China - Guangzhou 510320

luoqi@gdufe.edu.cn

*corresponding author

This version 19 June 2020 


\section{Introduction}

It has been increasingly recognized in the literature that the institutional influence of colonization is a key determinant accounting for the comparative development in the long run. The persistent impacts that the historical legacies have exerted both formal and informal institutions of the former colonies range from legal systems, law enforcement, religious background, social norms and culture values (Acemoglu, Johnson, \& Robinson, 2001; 2002; 2005; Acemoglu \& Robinson, 2005; Banerjee \& Iyer, 2005; La porta., Lopez-de-Silanes, \& Shleifer, 2008; Guiso, Sapienza, \& Zingales., 2009; 2016; Becker, Boeckh, Hainz, \& Woesmann, 2016; Dell \& Olken, 2020).

With the defeat in the first opium war followed by the treaty of Nanjing in 1842, China started to cede control several coastal cities to the British. Subsequently, there were numerous treaty ports established across China concessions of more colonial powers. These countries introduced their own legal systems, social policies, and infrastructures including schools, transportations and industries that served to maintain and facilitate their influence sphere. Most of these concessions were dissolved during the World War 2 and the second Sino-Japanese War (1937-1945) or in its instant aftermath. The main exceptions are British possession Hongkong (back in Chinese sovereignty in 1997) and Portuguese possession Macau (back in Chinese sovereignty in 1999). With the victory of the communist party in the Chinese civil war (1945-1949) after the World War 2 against the nationalist party, the People's Republic of China was established in 1949. Under the new regime, most of the former concessions were subject to central planning, price control and tight regulations. As all other parts of China, their connections with the world were largely restricted until the economic reform initiated in early 
1980s.

To what extent the historical legacy accounts for the rapid development of China over the past decades is of increasing interest. Lu and Tao (2009) find that the contract enforcement in privatized entrepreneurship is stronger in those regions that were British concessions, showing a persistent influence on peoples' social norms and business regulations. Jia (2014) ascribes the population growth of China to the legacies of old treaty ports along the Yangtze River and coastal areas by showing the population in these treaty ports grow faster than their counterparts. Chen, Wang, and Yan (2014) provide empirical evidence that the presence of Protestantism after the colonization took place in Chinese modern history generates a positive effect on long-term economic growth, educational development and healthcare systems. Wang and Luo (2020) also find a significant long-term effect of colonial legacy on economic growth via foreign capital inflow.

In this paper, we investigate how colonial legacy affects China's long run development with a focus on the effect of inward FDI on labor market. Since the reform and opening-up policies, China has gradually become one of the largest FDI recipients for its favorable multinational policies, global business market and importantly, the low labor cost. Over the past decades, the amount of inward FDI has climbed steadily even after the financial crisis in 2008, reaching 1349 hundred million USD in 2018 alongside an increasing number of labor force in China (see Fig.1). There has been by far an extensive body of literature focusing on the effect of inward FDI on labor market (e.g., Feenstra \& Hanson, 1997; Figini \& Görg, 1999; 2011; Fosfuri, Motta, \& Rønde, 2001; Fu \& Balasubramanyam, 2005; Waldkirch, Nunnenkamp, \& Bremont., 2009; Rong, Liu, Huang, \& Zhang, 2020). Although most of these studies provide comprehensive insights into 
how labor market coevolves with the inward FDI in various aspects such as wage rates, wage inequality, employment, and labor mobility and productivity from firm-level, industry-level, regional-level, and country-level evidence, few of them has sought to consider the institutional factors, which play an essential role in understanding FDI-related strategic behaviors (Dunning \& Lundan, 2008; Cantwell, Dunning, \& Lundan, 2010; Bruno, Bytchkov, \& Estrin, 2013). Therefore, towards a better understanding the mechanism on how inward FDI affects the labor market, the ongoing debate necessitates a well-defined framework to explicate the institutional context for the FDI, which is largely neglected in the current literature.

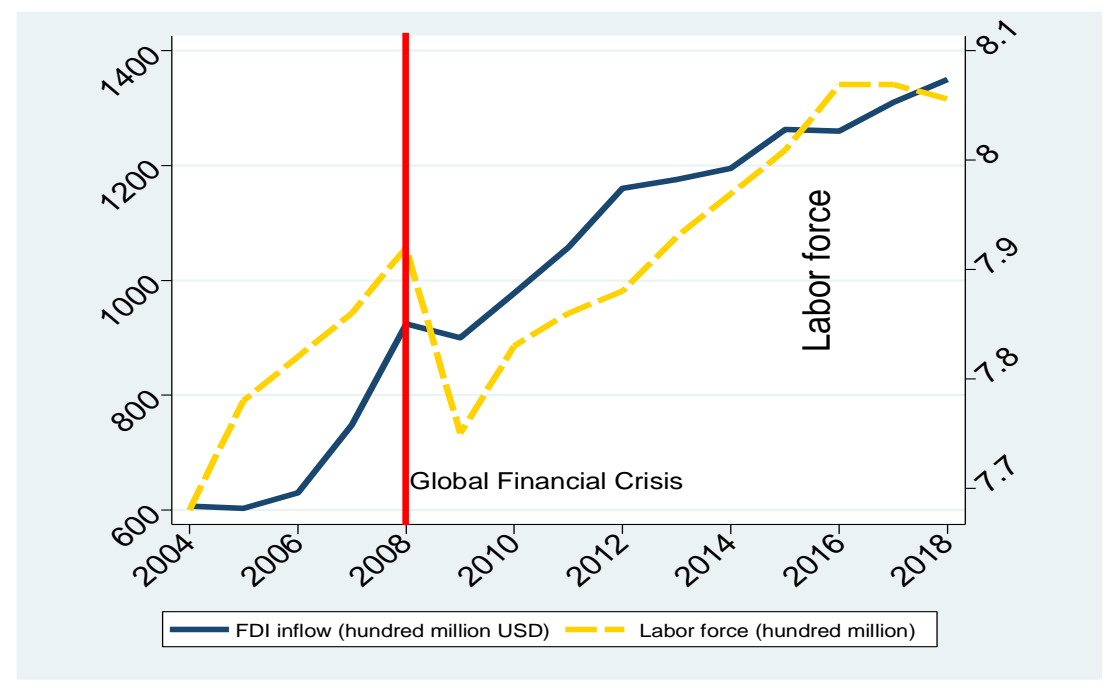

Fig. 1. Chinese inward FDI and Labor force. Source: Authors' plot based on NBSC.

Drawing our conceptual framework from the theory of the colonial institutions, we attempt to fill this gap by exploring how the colonial origins and the length of colonization affect the employment effect of inward FDI. In specific, we conduct a city-level panel empirical analysis on the basis of 288 Chinese cities and prefectures from 2011 to 2017. To compare the noncolonized and colonized cities, we are primarily interested in the interactive effect between inward FDI and the colonization experience. Like most of the previous studies, we first use the conventional measure of colonization experience (i.e. a dummy variable indicating whether the 
city was a former colony). We then take the length of colonization into accounts by constructing a set of colonization indices to capture the intensity of the colonization experience at city level. For a preview of the findings, we first demonstrate a positive relationship between inward FDI and employment. The key finding then to emerge from our study is that the employment effect of FDI at the city level is significantly affected by its colonial legacy. Comparing two different natures of colonization experience, we further show that the employment effect is strengthened by the Western colonization experience while such an effect is overturned by Japanese colonization experience.

The contributions of this paper are threefold. We first bridge the gap between the literature of FDI-labour market and the literature of historical legacies' influence by offering novel insights into how colonization affects the employment effect of inward FDI. A previous study by Wang, Fidrmuc and Tian (2018) has shed some light on this by focusing particularly on Chinese service sector. However, a major limitation of their study is its use of the provincial level data as colonization experience for China largely took place at city level. Using a different sample of Chinese cities, we pursue this avenue further by controlling for the city level heterogeneity to mitigate the potential unobservable variables problem. Moreover, to cope with the reverse causality between inward FDI and employment, we employ both static panel analysis with instrumental variable approach and dynamic panel analysis with system GMM.

Second, our study is also closely related to a broader literature on the historical ties and development outcomes. The underlying mechanisms explaining the long-run effect of historical legacies include property rights (Acemoglu et al., 2001), legal systems (La porta et al., 2008), social norms (Becker et al., 2016), cultural values (Guiso et al., 2009; Guiso et al., 2016), and 
human capital (Becker \& Woessmann, 2009; Acemoglu, Gallego, \& Robinson, 2014). Our results indicate that inward FDI might play a significant role in rekindling the bygone colonial rule, which is in line with the view of Alfaro, Klemmli-Ozcan, and Volosovych (2008) and Jia (2014) along with the empirical evidence from Long, Murrell and Yang (2019) that foreign capital might serve as an important mechanism via which institutions affect long-run development.

Third, we further distinguish between the Western and the Japanese colonization in our FDI and employment analysis. extant studies focusing on the legacy of foreign influence in China do not always concur. One strand of the literature suggests that the colonial legacy has a positive long-run effect on China's state institutions to better development outcomes in terms of education rate, population growth, bureaucratic efficiency, economic growth, and foreign investment (Jia, 2014; Mattingly, 2017; Long, Murrell, \& Yang, 2019; Wang \& Luo, 2019) whereas other studies show that the conflicts from the colonial period exerts detrimental impacts that overwhelms the state-building efforts (Che, Du, Lu, \& Tao, 2015; Gao, Wang, \& Che, 2018). Such conflicting views results in part from the lack of consideration of the different natures of colonization. To help reach a consensus, we provide a pertinent explanation that emphasize the different nature. The Western colonization was mainly motivated by trade while the Japanese colonization was ingrained with imperialism.

The remainder of our paper proceeds as follows. Section 2 reviews the literature of inward FDI and employment. Section 3 presents the conceptual framework and introduces our research hypotheses. Section 4 outlines the data and specifies the methodology. Section 5 carries out the empirical analysis and discusses the results. Section 6 concludes. 


\section{Inward FDI and employment}

The literature has investigated the employment effect of inward FDI from various aspects. From the perspective of labor classification, inward FDI has different impacts on two different types of labor, the skilled and unskilled. In the early attempts, Feenstra and Hansen (1997; 1999) study the impact of inward FDI on Mexico's labor market and find that the increasing outsourcing multinationals from other developed countries like the United States increase the wage for skilled workers and suppress that for unskilled workers, which corresponds to a higher demand for skilled workers and lower demand for unskilled workers. In light of this, a number of followup studies based on different samples then emerge and support that inward FDI can have impacts on skilled and unskilled workers by highlighting the relationship between inward FDI and wage inequality but conclude with fixed findings (e.g., Figini \& Görg, 1997; 1999; Driffield \& Taylor, 2005; Wan, Lu, \& Chen, 2007; Waldkirch et al., 2009; Chintrakarn, Herzer, \& Nunnenkamp, 2012; Herzer \& Nunnenkamp, 2013). Such mixed findings might be largely attributed to national discrepancy. Therefore, employment effect of inward FDI can be either positive or negative depending on the net effect of inward FDI on demand of the skilled and unskilled workers.

The employment effect of inward FDI may also differ in the short run and long run. For instance, Figini and Görg (2011) propose theoretical model to capture the effect of inward FDI. By utilizing the sample of 100 OECD and non-OECD countries, they detect a non-linear relationship between inward FDI and labor market with the findings showing that the inflow of inward FDI first exacerbates the skilled-unskilled wage inequality but then attenuate such inequality over the turning point in developing countries but not in developed countries. They 
further argue that this relationship is dynamic adjusted to different phases of the economy.

The interplay between foreign firms and domestic firms also plays a curial role in affecting the labor market. As inward FDI can exert spillover effects trough technology diffusions and know-how transfers, the domestic firms can benefit from the agglomeration effect and increase their productivity. Foreign multinationals can create positive linkages with local suppliers and customers by establishing business cooperation (i.e., purchasing and selling products and services from (to) each other) if they are in different vertical stages of production chain (i.e., the upstream and downstream industries) (Javorcik, 2004). The whole economy is scaled up through these mechanisms by the presence of foreign capital, which boots the labor market and stimulates the employment growth. However, inward FDI can also have a negative effect on employment even in the context of positive spillovers on productivity. If the substitution effect of inward FDI outstands, the new physical capital or advanced knowledge can replace the local labor and suppress employment in the host labor market (Wang et al., 2018). Not only the substitution effect can be detrimental to the employment but also the competition effect. For instance, domestic firms cannot avoid competing with foreign multinationals that are in principle more productive and in turn risk being crowded out in the market (Aitken \& Harrison, 1999), which is particularly salient for firms in the same industry (Lu, Tao, \& Zhu, 2017).

In addition, the employment effect of inward FDI is determined by FDI's entry strategy and ownership structure. If FDI enters as the form of greenfield investment, employment is expected to increase as a result of higher labor demand at the stage of initial setups (Wang et al., 2018). More specifically, driven by the low cost of migrant workers, joint ventures are more likely to have interactions with domestic firms (Ouyang \& Yao, 2017) whereas wholly foreign owned 
enterprises seem to display limited communications with domestic firms through the channel of technology diffusions and productivity spillovers (Javorcik, 2004; Girma, Gong, Görg, \& Lancheros, 2015) although inward FDI with the highest level of technology flows into host countries as wholly foreign owned enterprises rather than joint ventures (Javorcik \& Saggi, 2010). Therefore, the relationship between employment and inward FDI may differ by entry mode and ownership.

In the context of China, the employment effect of inward FDI has also been progressively documented. Using a sample of township and village enterprises in 29 provinces from 1987 to 1999, Fu and Balasubramanyam (2005) show that both export and inward FDI contribute significantly to the employment. Karlsson, Lundin, Sjöholm, and He (2009) also detect a positive relationship between employment and inward FDI in the Chinese manufacturing sector based on a firm-level data set from 1998 to 2004. Comparatively, Wang et al. (2018) utilize provincial level data from 2006 to 2015 and focus more on labor market in service sector. Their results show that inward FDI has a positive effect on employment in short run and long run. In a recent study, Rong et al. (2020) conduct a provincial level analysis and show that inward FDI promotes the employment in general as it increases the demand for both skilled and unskilled workers. They further show that wage, human capital and R\&D activity also play mediating role in the employment effect of inward FDI.

Despite that the existing literature on the association between inward FDI and labor market is flourishing, little efforts have been made to explicate such relationship taking institutional background into account, which leaves a significant research gap towards a fuller knowledge on the employment effect of inward FDI. As both formal and informal institutions such as 
cultural distance, property rights and rule of marketization significantly affect inward FDI in regard to its entry strategy, efficiency and location choice (Dunning, 1988; Xu \& Shenkar, 2002; Dunning \& Lundan, 2008; Estrin \& Uvalic, 2014), institutional factors will in turn determine the employment effect of inward FDI. Stemming from the institutional framework centering on the colonial ties, our study investigates how colonization experience affects the relationship between inward FDI and employment. We present the discussion of the conceptual framework, background and our research hypothesis in the following subsections.

\section{The role of colonial legacy}

Institutions are the fundamental causes of comparative developments across countries, which are crucially determined by their colonial origins and persist to present (Acemoglu et al., 2001). A considerable amount of literature has revealed that former colonies inherit long-term legacies that shape their current institutions. Their influence is either in the formal institutions such as legal systems (La porta et al., 2008), property rights (Banerjee \& lyer, 2005), democracy (Acemoglu et al., 2005), government spending (Huillery, 2009), bureaucracy (Becker et al., 2016) or in the form of informal institutions including social norms (Guiso et al., 2006), cultural values (Guiso et al., 2009; 2016). These institutional impacts have had profound social and economic consequences to this date. The long-lasting effect of colonization also applies to the cases in which bilateral investment occurs in countries that held colonial relationship. Jones and Khanna (2006) argue that history matters enormously for explaining the foreign direct investment and advocate more attempts from the historical perspective. Alfaro et al. (2008) suggest that foreign capital flow might be a channel connecting the institution and long-run development. (Head et 
al., 2010) further find that former colonies tend to trade and invest more frequently with their former colonizers due to familiar institutional environment and close cultural background.

These studies indicate that the colonial past can also have long-run impacts via inward FDI on employment. First, multinationals prefer to invest more in the former concessions with closer institutional and cultural environment as to reduce their operation and transaction cost. These regions also have inherited greater stocks of physical and human capital as the former colonizers invested into transportation and education system, which can help facilitate the setup, recruitment and maintenance of the multinationals. Second, the institutional familiarity and cultural affinity introduced by the colonization experience can not only attract more foreign capital but also enhance the communication and cooperation between foreign firms and local firms. This increases the output level and facilitates the technology and know-how diffusions, thereby enlarging the labor market by raising the demand for employment in down and upstream industries. Third, colonial rule has engendered greater trust and attitudes towards foreigners, including investors and the multinationals, among the regions' inhabitants, and it has also profoundly shaped the social norms and regulations, which in turn translating into employment effect of inward FDI. Therefore, the employment effect of inward FDI is positively shaped by the colonization experience.

However, central to the positive or negative effect of colonial legacy on the development is the nature of the colonial institutions, defined comparatively as inclusive institutions and extractive institutions (Acemoglu \& Johnson, 2012), with the former entailing the process of democracy and protecting the property rights to enhance long-run development whereas the latter serving for political elites to extract resource and to centralize the authority. Not only the 
formal institutional legacy matters, but also informal institutional legacy reflecting the historical relationship plays an important role (Guiso et al., 2016a; 2016b, Chowdhury \& Maung, 2018).

Based on this theory of colonial institutions, we argue that previous experience of colonization indirectly affects the relationship between inward FDI and employment through the institutional factor (as we discuss in section 2). If the colonial experience is inclusive, the current institutions are more likely to have democratic decision-making process, less corruption, more market-oriented and stronger property rights protection. This facilitates the operations of foreign firms, promote positive technological spillover effects to the domestic firms and boost the local economy and employment. If the colonial experience is exclusive, the current institutions are more likely to serve for political elites and authority to extract resource, have less protection for property rights, weaker local trust and hostile attitude towards foreign investors. This in turn does not benefit foreign and domestic firms and ultimately is detrimental for the local economy and employment. For this reason, we have our first hypothesis.

Hypothesis 1. Whether the colonial legacy can have a positive or negative effect on employment via inward FDI depends on the nature of colonization.

We pursue the above hypothesis further by distinguishing the natures of colonization, which can be categorized into Western and Eastern influence with two different legal, religious and cultural backgrounds and colonization intentions involved. The Western colonization were imposed by the Austria-Hungary, Belgium, the United Kingdom, France, Germany, Italy, Portugal, Russia (the Soviet Union) and the United States. The motivation of the Western powers was to open the market in China and promote their exports, and preach the gospel by 
missionary in this large Asian country. Therefore, the inclusive institution introduced was more likely to overwhelm the extractive institution and the casualties. Examples to this include Hongkong, as a remote fishery village, that has developed into one of the most advanced economies nowadays under the British institutions. Similarly, some other regions in mainland China such as Qingdao and Shamian island (Guangzhou), has benefited from the wellpreserved infrastructures such as architectures, drainage systems and railways. Besides, various missionary societies from Western countries set up schools in poor regions. These turn out to persistently affects the economic outcomes to this day. For instance, Chen et al. (2014) find that Protestant activities during the colonization period has a lasting and beneficial effect today's economic outcome regarding education and health care. These advantageous industrial and cultural heritage establish a favorable environment for the foreign investors. Long et al (2020) show that the legal origins of the Western colonization contribute greatly to attracting foreign capital in the early reform. Wang and Luo (2020) also detect a salient and positive effect of the Western colonization on economic growth in the long run through inward FDI. Accordingly, we have our second hypothesis.

Hypothesis 2. The Western colonial legacy has a positive effect on employment via inward FDI.

The Eastern colonization refers to the Japanese militarism in Chinese modern history. Japanese colonization was driven by the resource extraction and territorial conquest. Japan initially colonized the northeast China and set up a Manchukuo as its puppet state to facilitate the resource extraction and stable its intention to conquer the rest of China, which is followed by its full-scale invasion in 1937, known as the incident of Macro Polo Bridge. Under the 
Japanese colonization, severe state destruction effect was induced by this extractive institution such as the mistreatment of the innocent local civilians including the Nanjing Massacre and the human experiment for biochemical weapon by Unit 731 (Nana-san-ichi Butar). The effect of the Japanese colonization is also documented by several empirical studies. Klein, Ettenson, and Morris (1988) show that in Japanese colonized regions such as Nanjing, Chinese consumers eschew Japanese products even if the products are superior to products from other origins. Che et al. (2015) argue that the historical conflict has a long-term impact on the Japanese FDI in China. They find that Japanese multinationals are less likely to invest in the regions that suffered civilian casualties. Similarly, Gao et al. (2018) find that such conflict not only relates to the location choice of Japanese multinationals in China but also negatively affects their performance (i.e. return on assets). On the basis of data for 8646 Japanese enterprises in China, their evidence shows that the regions suffered from Japanese colonization are more likely to resist Japanese FDI than their counterparts, and Japanese FDI in these regions has a lower return on assets. These findings lead to our third hypothesis.

Hypothesis 3. Japanese colonial legacy has a negative effect on employment via inward FDI.

Admittedly, it is plausible that the effect of colonial legacy should depend on how long the colonization experience was. Therefore, we have our fourth hypothesis.

Hypothesis 4. The longer the colonization experience was, the more salient the effect of colonial legacy is. 


\section{Methodology}

\subsection{Data}

To examine the research hypotheses, we utilize a panel dataset containing 285 Chinese cities (at prefecture level or higher) from 2011 to 2017. This dataset has two advantages in comparison with previous studies. First, earlier studies are mostly based on cross sectional datasets. For example, Mattingly (2017) uses data at township level in 2000 to study the long run effect of Japanese colonial rule. A cross sectional analysis is of large concern as the issue of endogeneity or the omitted variable problem produced by the unobservable fixed and random factors cannot be controlled for. Second, a city-level panel analysis provides more precise evidence about colonial influence. Wang et al. (2018) adopt a panel data analysis at provincial level to investigate how historical legacies determine the relationship between inward FDI and labor market. Although a provincial-level panel analysis can serve better to solve omitted variable issue mentioned earlier, it may over measure the colonial influence when the whole province does not necessarily have the colonization experience. A city-level panel analysis can capture better the heterogeneity of foreign investment in different cities in the same province. Thus, it can capture the colonial influence more accurately and mitigate the endogeneity problem.

We collect the data from multiple sources. The city-level socio-economic characteristics including employment and inward FDI are from China City Statistical Yearbook (multiple years). Data for colonization experience at city level are mainly from Twichett and Fairbank (2008) and Nield (2010). They have recorded comprehensive colonization information about China from 1842 to 1955. Macau (Portuguese concession, 1557-1999), Hong Kong (British concession, 1841- 
1997), and Taiwan (Japanese concession, 1895-1945, and outside the control of Chinese communist party after 1949) are excluded to comply with the social-economic data which are unavailable for these regions. Table 1 lists the former colonized cities. There are 49 colonized cities and 236 non-colonized cities in our sample. Some of the cities in the table were subjected to multiple colonial influences in the past. Most of colonized cities are located in the coastal areas and along the Yangtze river as shown in Fig 2.

\section{Table 1}

List of colonized cities.

\begin{tabular}{ll}
\hline Colonial power & Colonized cities \\
\hline Austria-Hungary & Beijing, Tianjin \\
Belgium & Beijing, Tianjin \\
United Kingdom & Amoy, Beijing, Guangzhou Hongkong*, Jiujiang, Shanghai, Tianjin, Weihai, Wuhan \\
France & Beijing, Shanghai, Guangzhou, Zhanjiang, Tianjin, Kunming, Wuhan \\
Germany & Beijing, Qingdao, Tianjin, Wuhan \\
Italy & Beijing, Tianjin \\
Portugal & Macau* \\
Russia/Soviet Union & Beijing, Tianjin, Wuhan, Harbin \\
United States & Amoy, Beijing, Shanghai, Tianjin \\
Japan & Anshan, Baishan, Baicheng, Benxi, Chifeng, Chongqing, Changchun, Chaoyang, Dalian, \\
& Dandong, Fuxin, Fushun, Qingdao, Huludao, Hangzhou, Suihua, Hegang, Heihe, Harbin, \\
& Jilin, Jiamusi, Jinzhou, Jixi, Liaoyuan, Liaoyang, Mudanjiang, Panjin, Qiqihaer, Qitaihe, \\
& Shanghai, Siping, Shashi, Shenyang, Suzhou, Songyuan, Shuangyashan, Tieling, Tonghua, \\
& Taiwan*, Yingkou, Yichun, Weihai \\
\hline
\end{tabular}

Note: *, not in sample. 


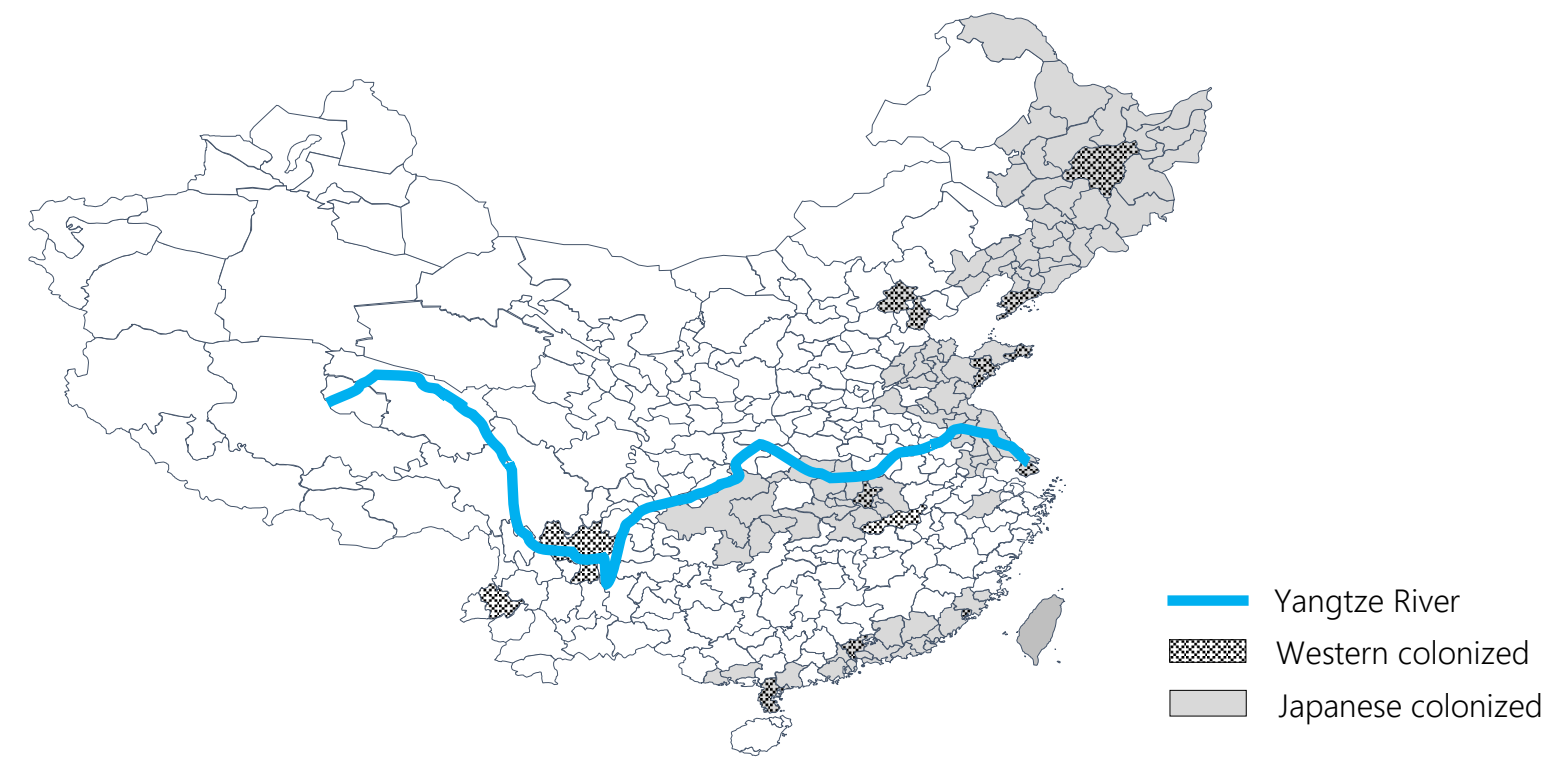

Fig. 2. Colonization in modern China, 1842-1955.

Table 2 summarizes the descriptive statistics. The employment, wage, GDP, FDI and human capital level are lower in non-colonized cities than in colonized cities but higher in the western colonized cities than Japanese colonized cities. As shown in Fig. 3, there is more a normal distribution of employment density in non-colonized cities sample than in colonized cities sample. More specifically, the employment density is more evenly distributed in the Western colonized cities whereas it is more concentrated in the lower tale in Japanese colonized cities. Fig. 4 outlines the relationship between inward FDI and outlines a positive relationship in general. This relationship seems to be particularly strong in former Western colonized cities as a larger proportion of observations lies above the fitted line.

Table 2

Descriptive statistics.

\begin{tabular}{|c|c|c|c|c|c|c|c|c|c|}
\hline \multirow{2}{*}{\multicolumn{2}{|c|}{ Variables }} & \multicolumn{2}{|c|}{ Non-colonized } & \multicolumn{2}{|c|}{ Colonized } & \multicolumn{2}{|c|}{ Western colonized } & \multicolumn{2}{|c|}{ Japanese colonized } \\
\hline & & \multirow{2}{*}{$\frac{\text { Mean }}{43.98}$} & \multirow{2}{*}{$\frac{S D}{43.21}$} & \multirow{2}{*}{$\begin{array}{l}\text { Mean } \\
94.09\end{array}$} & \multirow{2}{*}{$\frac{S D}{141.58}$} & \multirow{2}{*}{$\frac{\text { Mean }}{221}$} & \multirow{2}{*}{$\frac{S D}{206.58}$} & \multirow{2}{*}{$\frac{\text { Mean }}{56.95}$} & \multirow{2}{*}{$\begin{array}{c}\text { SD } \\
75.84\end{array}$} \\
\hline L & $\begin{array}{l}\text { Number of employment } \\
\text { (10000 people) }\end{array}$ & & & & & & & & \\
\hline W & $\begin{array}{l}\text { Average annual wage } \\
\text { (10000 yuan) }\end{array}$ & 4.98 & 1.46 & 5.01 & 1.86 & 6.60 & 2.31 & 4.56 & 1.34 \\
\hline Y & Gross domestic product & $1.90 e+07$ & $1.88 e+07$ & $4.00 e+07$ & $5.57 e+07$ & $9.20 \mathrm{e}+07$ & $7.52 e+07$ & $2.54 \mathrm{e}+07$ & $3.40 e+07$ \\
\hline
\end{tabular}


(10000 yuan)

\begin{tabular}{|c|c|c|c|c|c|c|c|c|c|}
\hline FDI & $\begin{array}{l}\text { Foreign direct investment } \\
\text { (10000 yuan) }\end{array}$ & 451890.3 & 747209.8 & 1510462.2 & 3163248.2 & 4236260.1 & 4561421.9 & $\begin{array}{c}1039070 . \\
2\end{array}$ & 1950707.5 \\
\hline $\mathrm{H}$ & $\begin{array}{l}\text { College enrollment (10000 } \\
\text { people) }\end{array}$ & 7.57 & 13.23 & 17.52 & 25.34 & 43.79 & 30.62 & 10.63 & 17.16 \\
\hline $\mathrm{SO}_{2}$ & $\begin{array}{l}\text { Sulfur dioxide emissions } \\
\text { (10000 tons) }\end{array}$ & 4.64 & 4.35 & 5.65 & 7.18 & 6.93 & 6.76 & 5.19 & 7.03 \\
\hline WW & $\begin{array}{l}\text { Wastewater emissions } \\
\text { (10000 tons) }\end{array}$ & 6022.20 & 5838.43 & 9100.38 & 12572.61 & 14083.65 & 11466.30 & 7365.54 & 12070.81 \\
\hline
\end{tabular}

Note: $\mathrm{SO}_{2}$ and $\mathrm{WW}$ are two instrumental variables which are discussed in detailed in the next section.
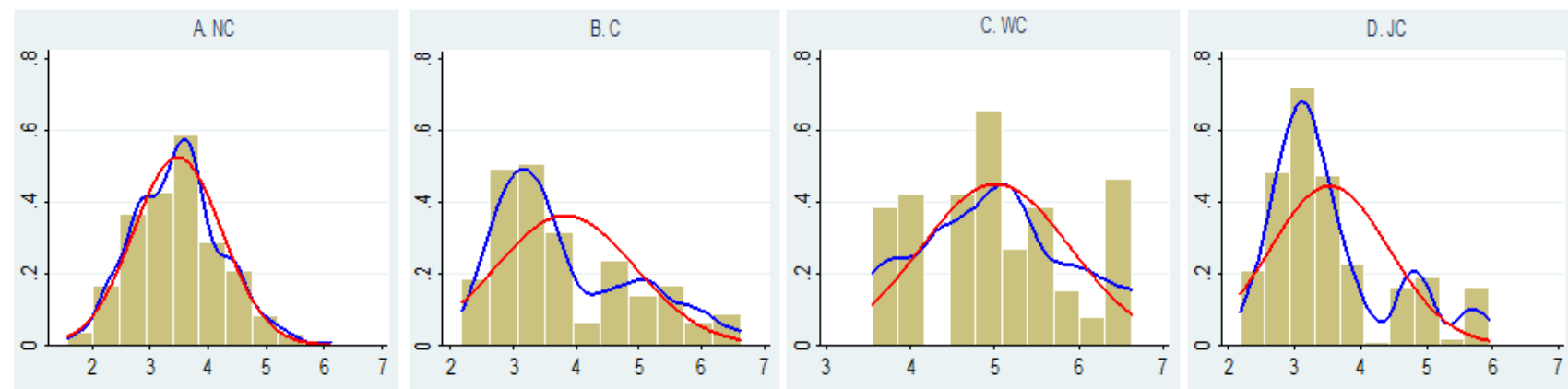

Fig. 3. Distribution of employment (in log form) in non-colonized cities (NC), colonized cities (C), the Western colonized cities (WC) and Japanese colonized cities (JC).

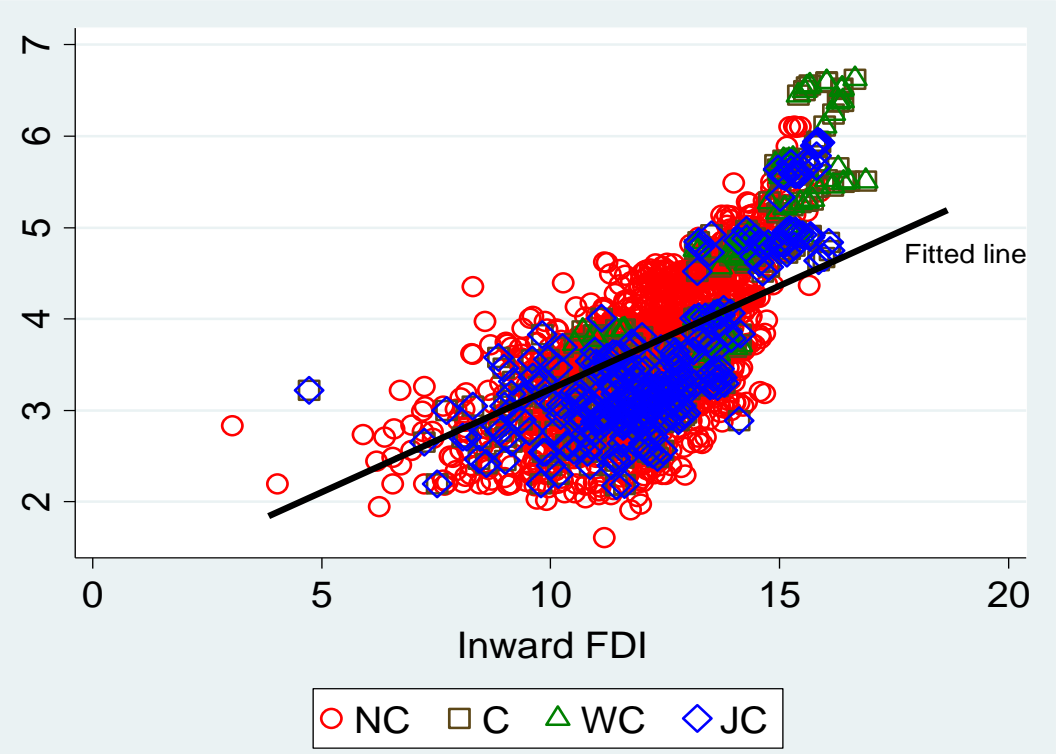

Fig. 5. Relationship between employment and inward FDI in non-colonized cities (NC), colonized cities, the Western colonized cities (WC) and Japanese colonized cities (JC). 


\subsection{Empirical strategy}

Our empirical model follows the theoretical framework of Hine and Wright (1998), Greenaway, Hine, and Wright (1999) and Fu and Balasubramanyam (2005). We elaborate on their model by explicitly adding a discussion on the goods and labor markets based on relevant works by Blanchard and Fischer (1989) and Blanchard, Amighini and Giavazzi (2013). This allows us to work out the price setting and wage demand equation that determines the (un)employment of the economy. We introduce a simplified production function specified as follows.

$$
Y_{i t}=A_{i t} L_{i t}
$$

Where $Y_{i t}$ denotes the real output; $L_{i t}$ the labor employed and $A_{i t}$ the total factor productivity (TFP). All these three variables are the level of city $i$ at year t. Assume that the TFP of city $i$ in year $t$ is determined by a number of factors that change over time as specified in the following equation.

$$
A_{i t}=A_{i} F D I_{i t}^{\delta_{1}} F D I_{i t}^{c^{g} \delta_{2}} H_{i t}^{\delta_{3}} \quad \delta_{1}, \delta_{2}, \delta_{3}>0
$$

Where $A_{i}$ is a given constant technological level of city $i ; F D I_{i t}$ denotes the inflows of foreign direct investment. $c^{j}$ denotes the colonization experience measuring for whether city $i$ is a former concession and subject to colonial power $g$; and $H_{i t}$ is human capital variable. There are three other factors that we consider. First, the technology diffusion and know-how transfer of inward FDI is a crucial factor contributing to the TFP. Second, based on the discussions earlier, we also take the view that historical legacy (i.e. the persistent effect of previous colonial ties with country j) shapes the efficiency of how FDI contributing to the TFP. Third, the human capital of city $i$ at year $t$ also plays a role in the TFP as emphasized in the endogenous growth 
literature. $\delta_{1}, \delta_{2}$ and $\delta_{3}$ are coefficients which measure the intensity of the positive effects of the three factors, respectively.

In a competitive goods market, firms which are profit-maximizing would set the price of a unit of output equal to marginal labor cost (after considering the TFP factor $A_{i t}$ ). But many goods markets are not competitive, and these firms have the market power to charge a price higher than their marginal cost. A simple way of capturing this fact is to assume that firms set their prices according to equation 3.

$$
P_{i t}=\frac{\left(1+\mu_{i}\right) W_{i t}}{A_{i t}}
$$

where $\mu_{i}>0$ measures the market power of cities. The higher the degree of competition is, the lower the mark-up is. Vice versa, the lower the degree of competition is, the higher the mark-up is. The price, $P_{i t}$, will exceed the marginal wage cost, $\frac{W_{i t}}{A_{i t}}$, by a factor equal to $\left(1+\mu_{i}\right)$.

In a labor market, workers demand real wage that reflect a number of factors shown in equation (4). The real wage depends on the labor market condition (i.e. employment) and the general bargain power of workers (indicated as $z_{i t}$ ). Both of these factors have a positive impact on the wage level demanded by workers (Blanchard et al., 2013).

$$
\frac{W_{i t}}{P_{i t}}=f\left(L_{i t}, z_{i t}\right)
$$

Equation (3) and (4) (after eliminating $\frac{W_{i t}}{P_{i t}}$ ) can be used to find the labor market equilibrium. We have:

$$
f\left(L_{i t}, z_{i t}\right)=\frac{A_{i t}}{\left(1+\mu_{i}\right)}
$$

Assume $f\left(L_{i t}, z_{i t}\right)=L_{i t} z_{i t}$ as the labor function. As a result, labor demand can be expressed 
as:

$$
L_{i t}=\frac{A_{i t}}{\left(1+\mu_{i}\right) z_{i t}}
$$

After taking logarithms, the labor demand function can be rearranged as:

$$
\ln L_{i t}=\ln A_{i t}-\ln \left(1+\mu_{i}\right)-\ln z_{i t}
$$

Using the specification of TFP in equation (2), we derive the labor demand equation in equation (8) that is directly related to our empirical model.

$$
\ln L_{i t}=\ln A_{i}+\delta_{1} \ln F D I_{i t}+\delta_{2} c^{g} \ln F D I_{i t}+\delta_{3} \ln H_{i t}-\ln \left(1+\mu_{i}\right)-\ln z_{i t}
$$

Our empirical equation used in this study, therefore, is described in equation (9).

$$
\ln L_{i t}=\beta_{1} \ln F D I_{i t}+\beta_{2} c^{g} \ln F D I_{i t}+\boldsymbol{\theta} \boldsymbol{X}_{i t}+\pi_{i}+\eta_{t}+\varepsilon_{i t}
$$

Where $\beta_{1}$ and $\beta_{2}$ are the coefficients that measure the employment impact of FDI (and its connection with previous colonial ties). $\boldsymbol{X}_{i t}$ is a set of time variant and city specific control variable vector such as human capital level as discussed in the theoretical model. Additionally, it includes the wage level and the output level with the former reflecting the bargaining level of the works and the latter reflecting the business cycle of the output. $\pi_{i}$ denotes unobservable city specific effect, this could be related to the institutional features at city level such as the degree of competition in the good market and labor market features such as labor protection level. $\varepsilon_{i t}$ denotes the error term. In this set up with the city level panel dataset, we can adopt a two-way fixed effect model to control for the unobserved confounders, the city specific effects, and the time-specific effects that may potentially affect the employment and bias the estimation 
if they are not taken into accounts.

5. Results

\subsection{Baseline estimates}

In this section, we present the results of the baseline estimation in Table 3. As our sample is a panel dataset, what concerns us is that the observations might subject to the bias of unobservable heterogeneity across the cities. For all regressions, the results of Hausman test are all significant at $1 \%$ percent, which suggests that city-specific unobserved confounders are related to the regressors and fixed effect is preferred. Year dummies are also included. Column 1 reports the results of the employment effect of inward FDI. The coefficient of inward FDI is statistically significant at $1 \%$, which presents a positive employment effect of inward FDI. 1\% increases in inflow of foreign capital yields approximately 0.06 percentage-points growth in employment. Column 2 includes the inward FDI interacted with the colonial influence in the regression for employment. The positive effect of inward FDI still holds. Consistent with hypothesis 1 , the coefficient of the interaction term is statistically significant and positive at 10\%, which suggests that positive effect of inward FDI is strengthened in the colonized regions in general than their counterparts. Regarding the nature of different colonization, columns 3, 4 and 5 display the results of the Western colonization and Japanese colonization in shaping the employment effect of inward FDI. In support of hypothesis 2, the positive employment effect of inward FDI is strengthened in the Western colonized regions with $1 \%$ increases in foreign capital increasing the employment by around 0.07\%. Adversely, however, such effect is depressed in Japanese colonized regions, showing that $0.08 \%$ employment shrinks when 
foreign capital increases by $1 \%$, which is consistent with hypothesis 3 . The coefficients of control variables are statistically significant. It confirms that: (1) growth of wage rates has a negative effect on employment; (2) increased output leads to higher labor demand; (3) human capital contributes positively to employment. These results are in line with previous studies (Hine \& Wright, 1998; Greenaway et al., 1999; Fu \& Balasubramanyam, 2005; Rong et al. 2020). 
Table 3

Colonization and the employment effect of inward FDI, FE.

\begin{tabular}{|c|c|c|c|c|c|}
\hline Variables & (1) & $(2)$ & (3) & (4) & (5) \\
\hline \multirow{2}{*}{$\ln W$} & $-0.122^{\star \star \star}$ & $-0.134^{\star \star \star}$ & $-0.122^{\star \star \star}$ & $-0.136^{\star \star \star}$ & $-0.135^{\star \star \star}$ \\
\hline & $(0.031)$ & $(0.032)$ & $(0.031)$ & $(0.32)$ & $(0.032)$ \\
\hline \multirow{2}{*}{$\ln Y$} & $0.630^{\star \star \star}$ & $0.645^{\star \star *}$ & $0.633^{\star \star \star}$ & $0.648^{\star \star *}$ & $0.651^{\star \star \star}$ \\
\hline & $(0.037)$ & $(0.038)$ & $(0.037)$ & $(0.038)$ & $(0.039)$ \\
\hline \multirow{2}{*}{$\mathrm{InH}$} & $0.037^{*}$ & $0.036^{*}$ & 0.030 & $0.041^{\star}$ & $0.032^{*}$ \\
\hline & $(0.021)$ & $(0.020)$ & $(0.021)$ & $(0.21)$ & $(0.017)$ \\
\hline \multirow{2}{*}{ InFDI } & $0.058^{* * *}$ & $0.075^{\star \star \star}$ & $0.055^{\star \star \star}$ & $0.076^{\star \star \star}$ & $0.075^{\star \star *}$ \\
\hline & $(0.020)$ & $(0.023)$ & $(0.020)$ & $(0.023)$ & $(0.023)$ \\
\hline \multirow{2}{*}{$\operatorname{lnFDI} \times C$} & & $0.071^{\star}$ & & & \\
\hline & & $(0.041)$ & & & \\
\hline \multirow{2}{*}{$\operatorname{lnFDI} \times W C$} & & & $0.075^{\star *}$ & & $0.063^{* \star}$ \\
\hline & & & $(0.037)$ & & $(0.032)$ \\
\hline \multirow{2}{*}{$\operatorname{InFDI} \times J C$} & & & & $-0.083^{*}$ & $-0.084^{\star}$ \\
\hline & & & & $(0.047)$ & $(0.047)$ \\
\hline \multirow{2}{*}{ Constant } & $-6.871^{\star \star \star}$ & $-7.112^{\star \star \star}$ & $-6.902^{* \star *}$ & $-7.231^{\star \star \star}$ & $-7.271^{\star \star \star}$ \\
\hline & $(0.578)$ & $(0.596)$ & $(0.580)$ & $(0.615)$ & $(0.616)$ \\
\hline City fixed & Yes & Yes & Yes & Yes & Yes \\
\hline Year fixed & Yes & Yes & Yes & Yes & Yes \\
\hline Observations & 1995 & 1995 & 1995 & 1995 & 1995 \\
\hline Adjusted $\mathrm{R}^{2}$ & 0.8603 & 0.8249 & 0.8471 & 0.8670 & 0.8392 \\
\hline Hausman / Wald $\chi^{2}$ (df) & $19.65^{\star \star \star}$ & $24.10^{\star \star \star}$ & $20.59 * \star \star$ & $19.80^{\star \star \star}$ & $21.72^{\star \star \star}$ \\
\hline
\end{tabular}

Notes: Significance level at *10 percent, ${ }^{*} 5$ percent, $* \star \star 1$ percent, respectively. Standard errors are in parentheses.

\subsection{The endogeneity}

The above analysis provides an initial evidence for the association between colonization and employment effect of inward FDI. However, it does not take account of the endogeneity problem. In specific, labor market can affect the location of inward FDI and thus the baseline estimates could be biased. To cope with this problem, we adopt the two stage least squares (2SLS) method, in which the inward FDI is considered endogenously determined. Two indicators on the emission level of industrial pollutants are employed as instrumental variables. One is the annual emission of industrial sulfur dioxide and the other is the annul emission of industrial 
wastewater (see Table 2 for their statistics). These two indicators are considered as a proxy for the stringency of environmental regulations in the framework of pollution haven hypothesis. That is, it has been documented that in many development countries including China, loosened environmental regulations (i.e. more tolerance towards environmental pollution) has a positive effect to attract more inward FDI flows (see Hoffman, Lee, Ramasamy, \& Yeung, 2005; Fu \& Zhang, 2008; Sun, Zhang, \& Xu, 2017). While these instrumental variables can affect the location of inward FDI, they seem to be less likely to affect employment directly.

Table 4 presents the results of 2SLS estimation. The Crag-Donald (first stage) F statistics for the weak instrument problem and the Sargan statistics for the over identification jointly confirm the validity of the two instrumental variables (IV) we employ. For all the regressions, the coefficient of both IVs, the industrial air pollutant indicators are statistically significant and positive, which is line with the literature of inward FDI and environmental pollution we discuss above. The coefficients of control variables maintain expected signs and statistically significant. Central to the objective of our study, inward FDI is shown to continue have a positive effect on employment. This positive effect is still intensified by the Western colonization and weakened and even overturned by the Japanese colonization. To be specific, we find a $1 \%$ increase in foreign investment leads to approximately 0.34 percentage-points growth in employment. Furthermore, this positive effective is intensified by an additional $0.13 \%$ growth in a previously Western colonized city but diminished by around $0.50 \%$ in a previously Japanese colonized city. Noticeably, the coefficients of the 2SLS regressions are larger than the ones in Table 3 . This shows that after controlling for the endogeneity, the colonial effects are more salient than previously revealed. 
Table 4

Colonization and the employment effect of inward FDI, 2SLS.

\begin{tabular}{|c|c|c|c|c|c|}
\hline Variables & (1) & (2) & (3) & (4) & (5) \\
\hline \multicolumn{6}{|l|}{ Second stage: InL } \\
\hline \multirow{2}{*}{$\ln W$} & $-0.130^{\star \star \star}$ & $-0.106^{\star \star \star}$ & 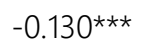 & $-0.074^{\star}$ & $-0.105^{\star \star \star}$ \\
\hline & $(0.042)$ & $(0.039)$ & $(0.042)$ & $(0.044)$ & $(0.039)$ \\
\hline \multirow{2}{*}{$\ln Y$} & $0.562^{\star \star *}$ & $0.659 * * *$ & $0.559 * * \star$ & $0.609 * * \star$ & $0.660 * \star *$ \\
\hline & $(0.051)$ & $(0.045)$ & $(0.052)$ & $(0.046)$ & $(0.045)$ \\
\hline \multirow{2}{*}{$\mathrm{InH}$} & $0.052^{\star \star}$ & $0.061^{\star \star}$ & $0.052^{\star *}$ & $0.064^{\star \star \star}$ & $0.059 * *$ \\
\hline & $(0.024)$ & $(0.026)$ & $(0.024)$ & $(0.027)$ & $(0.026)$ \\
\hline \multirow{2}{*}{$\operatorname{lnFDI}$} & $0.335^{\star \star \star}$ & $0.521^{\star \star}$ & $0.343^{\star \star \star}$ & $0.509^{\star \star \star}$ & $0.496^{\star \star \star}$ \\
\hline & $(0.128)$ & $(0.210)$ & $(0.130)$ & $(0.201)$ & $(0.204)$ \\
\hline \multirow{2}{*}{$\operatorname{lnFDI} \times C$} & & $0.513^{\star *}$ & & & \\
\hline & & $(0.212)$ & & & \\
\hline \multirow{2}{*}{$\operatorname{lnFDI} \times W C$} & & & $0.133^{* *}$ & & $0.171^{\star \star}$ \\
\hline & & & $(0.067)$ & & $(0.069)$ \\
\hline \multirow{2}{*}{$\operatorname{lnFDI} \times J \mathrm{C}$} & & & & $-0.681^{\star \star \star}$ & $-0.504^{\star \star \star}$ \\
\hline & & & & (0.181) & $(0.207)$ \\
\hline \multicolumn{6}{|l|}{ First stage: InFDI } \\
\hline \multirow{2}{*}{$\mathrm{InSO}_{2}$} & $0.062^{* \star *}$ & $0.041^{\star \star \star}$ & $0.059^{\star \star * \star}$ & $0.039^{\star \star *}$ & $0.042^{\star * \star}$ \\
\hline & $(0.013)$ & $(0.011)$ & $(0.013)$ & $(0.012)$ & $(0.012)$ \\
\hline \multirow{2}{*}{ InWW } & $0.041^{\star \star \star}$ & $0.025^{*}$ & $0.042^{\star \star}$ & $0.034^{\star \star}$ & $0.025^{\star}$ \\
\hline & $(0.017)$ & $(0.014)$ & $(0.017)$ & $(0.016)$ & $(0.015)$ \\
\hline Crag-Donald F Statistics & 19.25 & 10.40 & 18.24 & 10.64 & 10.74 \\
\hline Sargan (p-value) & 0.556 & 0.544 & 0.597 & 0.777 & 0.456 \\
\hline City fixed & Yes & Yes & Yes & Yes & Yes \\
\hline Year fixed & Yes & Yes & Yes & Yes & Yes \\
\hline Observations & 1995 & 1995 & 1995 & 1995 & 1995 \\
\hline Adjusted R² & 0.176 & 0.179 & 0.170 & 0.169 & 0.101 \\
\hline
\end{tabular}

Notes: Significance level at *10 percent, $* \star 5$ percent, $* \star \star 1$ percent, respectively. Standard errors are in parentheses.

\subsection{The intensity of colonization}

As in other studies, we use different sets of dummies to capture the colonial influence in the above estimates. This measure, however, is arguably problematic, especially in the case of China. The results under this measure are potentially driven by the coastal-inland disparity as most of the colonized regions are in coastal areas, which could lead to bias. More importantly, some of the concessions were occupied by both the Western and Japanese powers and thus dummy 
variables cannot distinguish the effect of one from another, resulting in misidentification. Additionally, although the occurrence of colonization matters, the duration, which is largely ignored in the literature, should be address (i.e., hypothesis 4). To do this, we garner more information for the colonization experience in each colonized city and construct an index for the colonization intensity. We consider the length (i.e. number of years) of colonization as a proportion of the modern history of China during which foreign concessions were present in China. The Colonization index $(\mathrm{Cl})$ is, therefore, constructed as follows.

$$
\mathrm{CI}_{\mathrm{i}}=\sum_{\mathrm{c}} \text { Length of colonization }_{\mathrm{ic}} / \text { Length of Chinese modren history }
$$

where $\mathrm{CI}_{\mathrm{i}}$ is the colonization index in city $\mathrm{i}$. c denotes the colonial power. The length of Chinese modern history is calculated from the rectification of treaty of Nanking in 1842 till the last formal dissolution of the concession, the Russian Dalian in 1955. Similarly, to distinguish the Western colonization from Japanese colonization, we construct the following two indices.

$$
\begin{gathered}
\mathrm{WCI}_{\mathrm{i}}=\sum_{\mathrm{w}} \text { Length of the Western colonization } \\
\mathrm{iw} / \text { Length of Chinese modren history } \\
\mathrm{JCI}_{\mathrm{i}}=\text { Length of Japanese colonization } \mathrm{ij}_{\mathrm{ij}} / \text { Length of Chinese modren history }
\end{gathered}
$$

where $\mathrm{WCI}_{\mathrm{i}}$ and $\mathrm{JCI}_{\mathrm{i}}$ are the Western colonization intensity and Japanese colonization intensity in city $\mathrm{i}$, respectively; $\mathrm{w}$ denotes the Western colonial power and $\mathrm{j}$ denotes the Japan, respectively. Table $\mathrm{A} 1$ and $\mathrm{A} 2$ in the appendix display the value of different indices in which there is a large variation in their value due to the different duration of the colonization. In this sense, we can further identify whether the effect of colonization experience comes from the Western colonization or Japanese colonization. 
Table 5 reports the estimate outcomes using the colonization intensity indices. The results with fixed effect are shown in columns 1, 3, 5 and 7 and the results with 2SLS are shown in columns 2, 4, 6 and 8. Again, the results are consistent with those presented in Table 3 and Table 4. The employment effect of inward FDI is more pronounced in the 2SLS estimates. The coefficients of the interaction terms between inward FDI and colonization intensity turn to be statistically significant when the endogeneity issue is mitigated. Consistently, we find that the coefficients are larger and more significant in the positive effect of the Western colonization intensity and the negative effect of Japanese colonization intensity. This means that the longer the colonization a city experience, the greater the colonial influence reveals, which supports our hypothesis 4 . We also examine the colonial influence of each Western country individually as a robustness check. The results are presented in Table 6 . We find that the net positive effect is a joint force of different Western influence toward the same direction, which is in line with the main results.

\section{Table 5}

Colonization intensity and the employment effect of inward FDI.

\begin{tabular}{|c|c|c|c|c|c|c|c|c|}
\hline Variables & (1) & (2) & (3) & (4) & (5) & (6) & (7) & (8) \\
\hline \multirow[t]{2}{*}{$\ln W$} & $-0.123^{\star \star \star}$ & $-0.136^{\star \star}$ & $-0.123^{\star \star \star}$ & $-0.138^{\star \star}$ & $-0.132^{\star \star *}$ & $0.137^{\star \star \star}$ & $0.136^{\star \star}$ & $-0.093^{\star \star}$ \\
\hline & $(0.031)$ & $(0.053)$ & $(0.030)$ & $(0.052)$ & (0.031) & $(0.044)$ & (0.031) & (0.041) \\
\hline \multirow[t]{2}{*}{$\ln Y$} & $0.630 * \star \star$ & $0.555^{\star \star \star}$ & $0.631^{\star \star \star}$ & $0.559 * * *$ & $0.641^{\star \star \star}$ & $0.609 * * *$ & $0.658^{\star \star *}$ & $0.641^{\star \star}$ \\
\hline & $(0.037)$ & $(0.053)$ & $(0.037)$ & $(0.052)$ & $(0.038)$ & $(0.046)$ & $(0.038)$ & $(0.044)$ \\
\hline \multirow[t]{2}{*}{$\mathrm{InH}$} & $0.031^{\star}$ & $0.055^{\star \star}$ & $0.029 *$ & $0.052^{\star \star}$ & $0.031^{\star}$ & $0.064^{\star \star}$ & $0.032^{*}$ & $0.061^{\star \star}$ \\
\hline & $(0.17)$ & $(0.024)$ & $(0.016)$ & $(0.023)$ & $(0.017)$ & $(0.026)$ & $(0.19)$ & $(0.026)$ \\
\hline \multirow[t]{2}{*}{ InFDI } & $0.059^{\star \star \star}$ & $0.373^{\star \star \star}$ & $0.057^{\star \star \star}$ & $0.343^{\star * \star}$ & $0.072^{\star \star \star}$ & $0.510^{\star \star}$ & $0.076^{\star \star \star}$ & $0.477^{\star \star}$ \\
\hline & $(0.020)$ & $(0.143)$ & $(0.020)$ & $(0.133)$ & $(0.031)$ & $(0.201)$ & $(0.023)$ & (0.189) \\
\hline \multirow[t]{2}{*}{$\operatorname{lnFDI} \times \mathrm{Cl}$} & 0.106 & $0.164^{*}$ & & & & & & \\
\hline & $(0.064)$ & $(0.097)$ & & & & & & \\
\hline \multirow[t]{2}{*}{$\mathrm{InFDI} \times \mathrm{WCl}$} & & & $0.126^{\star *}$ & $0.133^{\star *}$ & & & $0.178^{\star *}$ & $0.284^{* \star}$ \\
\hline & & & $(0.059)$ & $(0.057)$ & & & $(0.108)$ & (0.123) \\
\hline \multirow[t]{2}{*}{$\mathrm{InFDI} \times \mathrm{JCl}$} & & & & & $-0.412^{\star}$ & $-0.574^{\star \star \star}$ & $-0.393^{\star}$ & $-0.484^{\star \star \star}$ \\
\hline & & & & & $(0.281)$ & $(0.197)$ & $(0.218)$ & $(0.174)$ \\
\hline
\end{tabular}




\begin{tabular}{|c|c|c|c|c|c|c|c|c|}
\hline Crag-Donald F Statistics & & 16.19 & & 18.24 & & 10.65 & & 11.87 \\
\hline $\begin{array}{l}\text { Sargan Statistics ( } p- \\
\text { value })\end{array}$ & & 0.715 & & 0.597 & & 0.778 & & 0.523 \\
\hline City fixed & Yes & Yes & Yes & Yes & Yes & Yes & Yes & Yes \\
\hline Year fixed & Yes & Yes & Yes & Yes & Yes & Yes & Yes & Yes \\
\hline Observations & 1995 & 1995 & 1995 & 1995 & 1995 & 1995 & 1995 & 1995 \\
\hline Adjusted $\mathrm{R}^{2}$ & 0.846 & 0.150 & 0.859 & 0.170 & 0.855 & 0.156 & 0.846 & 0.152 \\
\hline Estimation method & $\mathrm{FE}$ & $2 S L S$ & $\mathrm{FE}$ & 2SLS & $\mathrm{FE}$ & $2 S L S$ & FE & $2 S L S$ \\
\hline
\end{tabular}

Notes: Significance level at *10 percent, $* \star 5$ percent, ${ }^{\star \star \star} 1$ percent, respectively. Standard errors are in parentheses.

\section{Table 6}

Individual colonial influence of Western countries.

\begin{tabular}{|c|c|}
\hline Variables & (1) \\
\hline \multirow[t]{2}{*}{ lnFDI $\times$ Austro-Hungary } & $0.146^{\star * *}$ \\
\hline & $(0.040)$ \\
\hline \multirow[t]{2}{*}{ lnFDI $\times$ Belgium } & $0.136^{\star \star \star}$ \\
\hline & $(0.033)$ \\
\hline \multirow[t]{2}{*}{ InFDI $\times$ France } & $0.082^{* * *}$ \\
\hline & $(0.023)$ \\
\hline \multirow[t]{2}{*}{ InFDI $\times$ Germany } & $0.136^{\star * \star}$ \\
\hline & $(0.033)$ \\
\hline \multirow[t]{2}{*}{$\operatorname{lnFDI} \times$ Italy } & $0.129 * * *$ \\
\hline & $(0.032)$ \\
\hline \multirow[t]{2}{*}{ InFDI $\times$ Russia/Soviet Union } & $0.123^{* \star *}$ \\
\hline & $(0.031)$ \\
\hline \multirow[t]{2}{*}{ InFDI $\times$ United States } & $0.132^{\star \star \star}$ \\
\hline & $(0.033)$ \\
\hline \multirow[t]{2}{*}{ lnFDI $\times$ United Kingdom } & $0.073^{* * *}$ \\
\hline & $(0.023)$ \\
\hline
\end{tabular}

Notes: Significance level at *10 percent, $* \star 5$ percent, $* \star * 1$ percent, respectively. Standard errors are in parentheses. All regressions were conducted individually due to multicollinearity.

\subsection{Robustness check: dynamic panel analysis}

Thus far, the empirics are conducted based on static panel analyses. In this section, we follow several studies under the assumption that the employment adjustment in the labor market is dynamic (e.g., Hine \& Wright, 1998; Fu \& Balasubramanyam, 2005; Waldkirch et al., 2009). We adopt the system GMM approach as a robustness check. This approach, compared to the 
difference GMM approach, can address the problem of individual heterogeneity, correct the deviation of missing data, and alleviate any issue of weak instrument that may arise (see discussion in Arellano and Bond (1991), Arellano and Bover (1995), and Blundell and Bond (1998)).

Table 7 presents the results for the colonization intensity and the employment effect of inward FDI with system GMM estimators. In all cases, the statistically insignificant Sargan statistics validate the instruments. The negative first-order serial correlation and the insignificant of second-order serial correlation indicate that the moment conditions are correctly specified. For all regressions, the lagged dependent variable is strongly positive, which shows that the employment in the previous year can effectively predict the current employment. The coefficients of control variables are in with those in static panel analysis. More importantly, we also find inward FDI has a positive effect on employment. This effect is positively moderated with the Western colonial influence but negatively moderated by Japanese colonial influence. The colonization effect is shown to be much stronger in GMM estimation, especially for the Japanese colonization as $1 \%$ increase in the Japanese colonization intensity decreases the employment by $0.82 \%$ to $1.11 \%$, which is more than twice the results in Table 5 . We believe possible explanations for the sizable difference may be related to the more efficient instrumental variables that are in use in the GMM than in the 2SLS approach. 


\section{Table 7}

Colonization intensity and the employment effect of inward FDI, system GMM.

\begin{tabular}{|c|c|c|c|c|c|}
\hline Variables & (1) & $(2)$ & (3) & (4) & (5) \\
\hline \multirow[t]{2}{*}{ L1. $\ln \mathrm{L}$} & $0.236^{\star \star *}$ & $0.252^{* * \star}$ & $0.275^{\star \star \star}$ & $0.261^{\star \star \star}$ & $0.317^{\star \star \star *}$ \\
\hline & $(0.044)$ & $(0.080)$ & $(0.089)$ & $(0.071)$ & $(0.082)$ \\
\hline \multirow[t]{2}{*}{$\ln W$} & $-0.386^{\star \star \star}$ & $-0.393^{* *}$ & $-0.399 * * *$ & $-0.435^{\star \star \star}$ & $-0.444^{\star \star \star}$ \\
\hline & $(0.089)$ & $(0.053)$ & $(0.094)$ & $(0.117)$ & $(0.116)$ \\
\hline \multirow[t]{2}{*}{$\ln Y$} & $0.958^{\star \star *}$ & $0.726^{\star \star \star}$ & $0.718^{\star \star \star}$ & $0.421^{\star \star \star}$ & $0.741^{\star \star \star}$ \\
\hline & $(0.106)$ & $(0.117)$ & $(0.123)$ & $(0.099)$ & $(0.134)$ \\
\hline \multirow[t]{2}{*}{$\ln \mathrm{H}$} & $0.064^{*}$ & $0.055^{\star}$ & $0.063^{*}$ & $0.052^{* *}$ & $0.039^{*}$ \\
\hline & $(0.033)$ & $(0.031)$ & $(0.036)$ & $(0.023)$ & $(0.024)$ \\
\hline \multirow[t]{2}{*}{$\operatorname{lnFDI}$} & $0.099 * * \star$ & $0.109 * \star$ & $0.084^{\star \star}$ & $0.135^{\star \star}$ & $0.111^{\star \star}$ \\
\hline & $(0.029)$ & $(0.048)$ & $(0.042)$ & $(0.055)$ & $(0.045)$ \\
\hline \multirow[t]{2}{*}{$\operatorname{lnFDI} \times \mathrm{Cl}$} & & $0.232^{\star *}$ & & & \\
\hline & & $(0.097)$ & & & \\
\hline \multirow[t]{2}{*}{$\operatorname{lnFDI} \times \mathrm{WCl}$} & & & $0.226^{\star *}$ & & $0.267^{\star \star *}$ \\
\hline & & & $(0.114)$ & & $(0.078)$ \\
\hline \multirow[t]{2}{*}{$\operatorname{lnFDI} \times \mathrm{JCl}$} & & & & $-0.823^{\star \star}$ & $-1.110^{\star \star \star}$ \\
\hline & & & & $(0.418)$ & $(0.414)$ \\
\hline AR (1) & $-3.425^{\star \star \star}$ & $-4.681^{* \star *}$ & $-5.096^{\star * *}$ & $-2.949^{* \star *}$ & $-4.368^{* * *}$ \\
\hline AR (2) & 1.242 & 0.915 & 1.173 & 1.232 & 1.619 \\
\hline \multicolumn{6}{|l|}{ value) } \\
\hline Observations & 1710 & 1710 & 1710 & 1710 & 1710 \\
\hline F-Statistics & 337.06 & 725.61 & 348.37 & 350.32 & 891.87 \\
\hline
\end{tabular}

Notes: Significance level at *10 percent, $* \star 5$ percent, $* \star \star 1$ percent, respectively. Standard errors are in parentheses.

\section{Discussion and conclusion}

It has been increasingly recognized that historical legacy accounts widely for the development in the long run. This also leads to an interesting question about whether and how China, the world's largest emerging economy, has been related to the colonization experience in its modern history. Over the past years, the massive inflow of foreign capital and the low-priced labor are two main characteristics in the fast growth of Chinese economy. This motivates us to untangle the nuanced nexus among colonial legacy, inward FDI and labor market based on a panel data analysis of 285 Chinese cities over the period 2011-2017. 
We first demonstrate that inward FDI has a positive effect on employment in the Chinese labor market. This can be explained by that the entry of multinationals such as the exportoriented manufacturing joint ventures contributes greatly to expand the labor market and provides a vent for labor surplus (Fu \& Balasubramanyam, 2005), which is largely accounted from the bulk of rural labors languishing in rural low-productivity subsistence farming in China (Wang, Fidrmuc, Luo, \& Luo, 2020). The labor market flexibility further liberates these workforces into formal employment in the influx of the foreign capital (Rong et al., 2020). It should be noted that this employment growth is not only generated directly from the job creation of the foreign enterprises but also from the spillover effect of inward FDI driving the development of the industries especially for those in the upstream and downstream sectors (Javorcik, 2004; Karlsson et al., 2009; Lu et al., 2017). By controlling within-city effects, our study offers new evidence and complements the above literature that relies on either provincial level samples or firm level observations in the case of China.

We then advance the understanding of the inward FDI-employment relationship by showing that the positive employment effect is overall enhanced by the colonization experience of the cities, which is broadly consistent with the literature the highlights the persistent influence of historical legacy (Acemoglu et al., 2001; Banerjee \& Iyer, 2005; La porta et al., 2008; Alfaro et al., 2008; Becker \& Woessmann, 2009; Guiso et al., 2009; 2016; Becker et al., 2016; Dell \& Olken, 2020). In turn, we enrich the literature by examining the long-run development with focus on the labor market. In explaining why historical legacy has persistent effects, the existing studies point to several mechanisms including the formal institutions as the major channel, for example, for the development of India (Banerjee \& Iyer, 2005), Africa (Huillery, 2009) and Java (Dell \& 
Olken, 2020). As for the case of China, however, formal colonial institutions were essentially terminated although part of them were modified to fit in the Maoism and therefore, are less likely to represent the main mechanism. Rather, informal institutions such as social norms and human capital might have played a role (Jia, 2014). In support of Alfaro et al. (2008), Chowdhury and Maung (2018), and Long et al. (2020)1', our findings indicate that inward FDI is a major channel accounting for the long-run impact. We interpret this as that the presence of foreign capital revives at least partially the informal institutions such as social norms, business regulation and cultures that the colonization might have left, which accounts for such continual influence.

Of particular interest is our finding about the discrepancy of colonial influence. Differing from most of the prior studies, we separate two natures of colonization, which helps explain the unequivocal conclusions in the literature. On the one hand, we show that colonial legacy by the Western powers has a positive impact in shaping the employment effect of inward FDI, in line with the previous studies that colonial legacy has favorable impacts on business regulations, education, health systems, economic growth and foreign investment (Lu \& Tao, 2009; Chen et al, 2014; Wang et al., 2020; Long et al., 2020). On the other hand, we show that the Japanese colonial legacy has an adverse impact, which is coherent with the findings of Che et al. (2015) and Gao et al. (2018) that the Japanese historical legacy negatively affects trade and foreign investment. Intuitively, the positive effect of colonization comes from the Western influence that has left more advantageous institutions in which its state building efforts overpower the state destruction effects. Yet, the negative effect of colonization is attributed to

\footnotetext{
1 For example, see Alfaro et al. (2008, p.347) "Our results indicate that foreign investment might a channel through which institutions affect long-run development." Also see Chowdhury and Maung (2018) and Long et al. (2020) that provide evidence that historical legacy directly affects the foreign investment.
} 
the brutal and extractive regime of Japanese colonization.

As the first attempt to explore the impact of colonial legacy on employment effect of inward FDI at city level, our study faces some limitations. First, the heterogeneity of labor market such as skilled and unskilled employment or employment different industries should have been taken into accounts. Second, a fuller understanding should be on the basis of the heterogeneity of inward FDI with respect to its entry modes (i.e., joint ventures or wholly foreign owned) and sectoral distribution (primary sector, secondary sector and tertiary sector). Further, it would also be of interest to distinguish the origins of inward FDI as this should serve to more precisely capture the influence of the historical connections. Unfortunately, however, the city branches of the Chinese statistics bureau do not record these indicators in specific, which hinders this study from pursing these avenues any further. We would delve further into this issue if the refined data is available in the future. 


\section{References}

Acemoglu, D., \& Johnson, S. (2005). Unbundling institutions. Journal of Political Economy, 113(5), 949995.

Acemoglu, D., \& Johnson, S. (2012). Why Nations Fail. Crown Publishing Group.

Acemoglu, D., Gallego, F. A., \& Robinson, J. A. (2014). Institutions, human capital, and development. Annual Review of Economics, 6(91), 875-912.

Acemoglu, D., Johnson, S., \& Robinson, J. A. (2001). The colonial origins of comparative development: An empirical investigation. American Economic Review, 91(5), 1369-1401.

Acemoglu, D., Johnson, S., \& Robinson, J. A. (2002). Reversal of fortune: Geography and institutions in the making of the modern world income distribution. Quarterly Journal of Economics, 117(4), 12311294.

Acemoglu, D., Johnson, S., \& Robinson, J. A. (2005). The rise of Europe: Atlantic trade, institutional change, and economic growth. American Economic Review, 95(3), 546-579.

Aitken, B. J., \& Harrison, A. E. (1999). Do Domestic Firms Benefit from Direct Foreign Investment? Evidence from Venezuela. American Economic Review, 89(3), 605-618.

Alfaro, L., Kalemi-Ozcan, S., \& Volosovych, V. (2008). Why Doesn't Capital Flow from Rich to Poor Countries? An Empirical Investigation? Review of Economics and Statistics, 90(2), 347-368.

Arellano, M., \& Bong, S. (1991). Some tests of specification for panel data: Monte Carlo evidence and an application to employment equations. Review of Economic Studies, 58(2), 277-297.

Arellano, M., \& Bover, O. (1995). Another look at the instrumental variable estimation of errorcomponents models. Journal of Econometrics, 68(1), 29-51.

Banerjee, A., \& lyer, L. (2005). History, institutions, and economic performance: The legacy of colonial 
land tenure systems in India. American Economic Review, 95(4), 1190-1213.

Becker, S. O., \& Woessmann, L. (2009). Was Weber wrong? A human capital theory of Protestant economic history. Quarterly Journal of Economics, 124(2), 531-596.

Becker, S. O., Boeckh, K., Hainz, C., \& Woesmann, L. (2016). The Empire Is Dead, Long Live the Empire! Long-Run Persistence of Trust and Corruption in the Bureaucracy. Economic Journal, 126, 40-74.

Blanchard, O., \& Fischer, S. (1989). Lectures on macroeconomics. MIT press.

Blanchard, O., Amighini, A. \& Giavazzi, F. (2013). Macroeconomics: A European Perspective (2nd Edition), Prentice Hall.

Blundell, R., \& Bond, S. (1998). Initial conditions and moment restrictions in dynamic panel data models. Journal of Econometrics, 87(1), 115-143.

Bruno, R. L., Bythchkov, M., \& Estrin, S. (2013). Institutional Determinants of New Firm Entry in Russia: A Cross-Regional Analysis. Review of Economics and Statistics, 95(5), 1740-1749.

Cantwell, J., Dunning, J. H., \& Lundan, S. M. (2010). An evolutionary approach to understanding international business activity: The co-evolution of MNEs and the institutional environment. Journal of International Business Studies, 41(4), 567-586.

Che, Y., Julan, D., Yi, L., \& Tao, Z. (2015). Once an enemy, forever an enemy? The long-run impact of the Japanese invasion of China from 1937 to 1945 on trade and investment. Journal of International Economics, 96(1), 182-198.

Chen, Y., Wang, H., \& Yan, S. (2014). The Long-Term Effects of Protestant Activities in China. CEH Discussion Papers 025, Centre for Economic History, Australian National University.

Chintrakarn, P., Herzer, D., \& Nunnenkamp, P. (2012). FDI and income inequality: Evidence from a panel of U.S. states. Economic Inquiry, 50(3), 788-801. 
Chowdhury, R. H., \& Maung, M. (2018). Historical ties between nations: How do they matter in crossborder mergers and acquisitions? International Review of Economics and Finance, 58, 30-48.

Dell. M., \& Olken, B. A. (2020). The development effects of the extractive colonial economy: the Dutch cultivation system in Java. Review of Economic Studies, 87(1), 164-203.

Driffield, N., \& Taylor, K. (2000). FDI and the labour market: A review of the evidence and policy implications. Oxford Review of Economic Policy, 16(3), 90-103.

Dunning, J. H., \& Lundan, S. M. (2008). Multinational Enterprises and the Global Economy. Edward Elgar, Cheltenham.

Dunning, J. H., (1988). The theory of international production. International Trade Journal, 3, 21-66.

Estrin, S., \& Uvalic, M. (2014). FDI into transition economies: are the Balkans different? Economics of Transition, 22(2), 281-312.

Feenstra, R. C., \& Hanson, G. H. (1997). Foreign direct investment and relative wages: Evidence from Mexico's maquiladoras. Journal of International Economics, 42(3-4), 371-393.

Feenstra, R. C., \& Hanson, G. H. (1999). The impact of outsourcing and high-technology capital on wages: estimates for the United States, 1979-1990. Quarterly Journal of Economics, 114(3), 907-940.

Figini, P., \& Görg, H. (1999). Multinational companies and wage inequality in the host country: the case of Ireland. Weltwirtschaftliches Archiv, 135(4), 594-612.

Figini, P., \& Görg, H. (2011). Does Foreign Direct Investment Affect Wage Inequality? An Empirical Investigation. World Economy, 34(9), 1455-1475.

Fosfuri, A., Motta, M., \& Rønde, T. (2001). Foreign direct investment and spillovers through workers' mobility. Journal of International Economics, 53(2001), 205-222.

Fu, X., \& Balasubramanyam, V. N. (2005). Exports, foreign direct investment and employment: the case 
of China. World Economy, 28(4), 607-625.

Gao, G. Y., Wang, D. T., \& Che, Y. (2018). Impact of historical conflict on FDI location and performance: Japanese investment in China. Journal of International Business Studies, 49, 1060-1080.

Girma, S., Gong, Y., Görg, H., \& Lancheros, S. (2015). Investment liberalisation, technology take-off and export markets entry: Does foreign ownership structure matter? Journal of Economic Behavior \& Organization, 116, 254-269.

Greenaway, D., Hine, R. C., \& Wright, P. (1999). An empirical assessment of the impact of trade on employment in the United Kingdom. European Journal of Political Economy, 15(3), 485-500.

Guiso, L., Sapienza, P., \& Zingales, L. (2009). Cultural Biases in Economic Exchange? Quarterly Journal of Economics, 124(3), 1095-1131.

Guiso, L., Sapienza, P., \& Zingales, L. (2016a). Does Culture Affect Economic Outcomes? Journal of Economic Perspective, 20(2), 23-48.

Guiso, L., Sapienza, P., \& Zingales, L. (2016b). Long-Term Persistence. Journal of European Economic Association, 14(6), 1401-1436.

Head, K., Mayer, T., \& Ries, J. (2011). The erosion of colonial trade linkages after independence. Journal of International Economics, 81(1), 1-14.

Herzer, D., \& Nunnenkamp, P. (2013). Inward and outward FDI and income inequality: evidence from Europe. Review of World Economics, 149, 395-422.

Hine, R. C., \& Wright, P. (1999). Trade with low wage economies, employment and productivity in UK manufacturing. Economic Journal, 108, 1500-1510.

Hoffman, R., Lee, C., Ramasamy, B., \& Yeung, M. (2005). FDI and pollution: a granger causality test using panel data. Journal of International Development, 17(3), 311-317. 
Huillery, E. (2009). History matters: The long-term impact of colonial public Investments in French West Africa. American Economic Journal: Applied Economics, 1(2), 176-215.

Javorcik, B. S. (2004). Does Foreign Direct Investment Increase the Productivity of Domestic Firms? In Search of Spillovers Through Backward Linkages. American Economic Review, 94(3), 605-627.

Javorcik, B. S., \& Saggi, K. (2010). Technological asymmetry among foreign investors and mode of entry. Economic Inquiry, 48(2), 415-433.

Jia, R. (2014). The legacies of forced freedom: China's treaty ports. Review of Economics and Statistics, 96(4), 596-608.

Jones, G., \& Khanna, T. (2006). Bringing history (back) into international business. Journal of International Business Studies, 37, 453-468.

Karlsson, S., Lundin, N., Sjöholm, F., \& He, P. (2009). Foreign Firms and Chinese Employment. World Economy, 32(1), 178-201.

Klein, J. G., Ettenson, R., \& Morris, M. D. (1998). The animosity model of foreign product purchase: An empirical test in the Peoples' Republic of China. Journal of Marketing, 62(1), 89-100.

La Porta, R., Lopez-de-Silanes, F., \& Shleifer, A. (2008). The Economic Consequences of Legal Origins. Journal of Economic Literature, 46(2), 285-332.

Long, C., Murrell, P., \& Yang, L. (2019). Memories of colonial law: The inheritance of human capital and the location of joint ventures in early-reform China. China Economic Review. (in press).

Lu, Y., \& Tao, Z., (2009). Contract enforcement and family control of business: Evidence from China. Journal of Comparative Economics, 37(4), 597-609.

Lu, Y., Tao, Z., \& Zhu, L. (2017). Identifying FDI spillovers. Journal of International Economics, 107, 75-90. Mattingly, D. C. (2017). Colonial legacies and state institutions in China: Evidence from a natural 
experiment. Comparative Political Studies, 50(4), 434-463.

Nield, R. (2010). The China Coast: Trade and the First Treaty Ports. Hong Kong: Joint Publishing Company. North, D. C. (1990). Institutions, Institutional Change, and Economic Performance. Norton, New York.

Ouyang, P., \& Yao, S. (2017). Developing inland China: The role of coastal foreign direct investment and exports. World Economy, 40(11), 2403-2423.

Rong, S., Liu, K., Huang, S., \& Zhang, Q. (2020). FDI, labor market flexibility and employment in China. China Economic Review, in press.

Sun, C., Zhang, F., \& Xu, M. (2017). Investigating of pollution haven hypothesis for China: An ARDL approach with breakpoint unit root tests. Journal of Cleaner Production, 161, 153-164.

Twichett, D., \& Fairbank, J. K. (2008). The Cambridge History of China. Cambridge University Press.

Waldkirch, A., Nunnenkamp, P., \& Bremont, J. E. A. (2009). Employment Effects of FDI in Mexico's NonMaquiladora Manufacturing. Journal of Development Studies, 45(7), 1165-1183.

Wan, G., Lu, M., Chen, Z. (2007). Globalization and regional income inequality: Empirical evidence from China. Review of Income and Wealth, 53(1), 35-59.

Wang, H., \& Luo, Q. (2020). How colonial legacy shapes the impact of inward FDI on GDP? Evidence from China. Applied Economics Letters, 27(9), 740-743.

Wang, H., Fidrmuc, J., \& Tian, Y. (2018). Growing against the background of colonization? Chinese labor market and FDI in a historical perspective. International Review of Economics and Finance. (in press).

Wang, H., Fidrmuc, J., Luo, Q., \& Luo, M. (2020). Exploring the determinants of on-farm transitions: Evidence from rural China. Applied Economics, in press.

Xu, D., \& Shenkar, O. (2002). Institutional distance and the multinational enterprises. Academy of Management Review. 274), 608-618. 
Zhang, J., \& Fu, X. (2008). FDI and environmental regulations in China. Journal of the Asia Pacific Economy, 13(3), 332-353. 


\section{Appendix}

\section{Table A1}

Western colonization in Chinese cities.

\begin{tabular}{|c|c|c|c|c|c|c|c|}
\hline Western power & City & Province & Event & Established & Dissolved & Duration & Intensity \\
\hline \multirow[t]{3}{*}{ International } & Amoy & Fujian & Gulangyu island & 1903 & 1945 & 43 & $37.72 \%$ \\
\hline & Beijing & Beijing & Beijing legation quarter & 1861 & 1945 & 85 & $74.56 \%$ \\
\hline & Shanghai & Shanghai & Shanghai international settlement & 1863 & 1945 & 83 & $72.80 \%$ \\
\hline \multirow[t]{2}{*}{ Austria-Hungary } & Beijing & Beijing & Beijing legation quarter & 1861 & 1945 & 85 & $74.56 \%$ \\
\hline & Tianjin & Tianjin & Austro-Hungarian concession in Tianjin & 1902 & 1917 & 16 & $14.03 \%$ \\
\hline \multirow[t]{2}{*}{ Belgium } & Beijing & Beijing & Beijing legation quarter & 1861 & 1945 & 85 & $74.56 \%$ \\
\hline & Tianjin & Tianjin & Belgian concession in Tianjin & 1902 & 1931 & 30 & $26.31 \%$ \\
\hline \multirow[t]{9}{*}{ United Kingdom } & Amoy & Fujian & British concession in Amoy & 1852 & 1930 & 79 & $69.91 \%$ \\
\hline & Dalian & Liaoning & British concession in Dalian & 1858 & 1860 & 3 & $2.63 \%$ \\
\hline & Guangzhou & Guangdong & British concession in Shamian island & 1861 & 1945 & 85 & $74.56 \%$ \\
\hline & Hankou/Wuhan & Hubei & British concession in Hankou & 1861 & 1927 & 67 & $58.77 \%$ \\
\hline & Jiujiang & Jiangxi & British concession in Jiujiang & 1861 & 1927 & 67 & $58.77 \%$ \\
\hline & Shanghai & Shanghai & British concession in Shanghai & 1846 & 1863 & 18 & $15.78 \%$ \\
\hline & Weihai & Shandong & Weihaiwei leased territory & 1898 & 1930 & 33 & $38.60 \%$ \\
\hline & Weihai & Shandong & Liugong island & 1930 & 1940 & 11 & \\
\hline & Zhanjiang & Guangdong & British concession in Zhanjiang & 1861 & 1929 & 69 & $60.52 \%$ \\
\hline \multirow[t]{6}{*}{ France } & Amoy & Fujian & Gulangyu island & 1903 & 1945 & 43 & $37.72 \%$ \\
\hline & Beijing & Beijing & Beijing legation quarter & 1861 & 1945 & 85 & $74.56 \%$ \\
\hline & Guangzhou & Guangdong & French concession in Shamian island & 1861 & 1946 & 86 & $75.43 \%$ \\
\hline & Hankou/Wuhan & Hubei & French concession in Hankou & 1896 & 1946 & 51 & $44.74 \%$ \\
\hline & Kunming & Yunnan & French railway, Kunming & 1904 & 1940 & 37 & $32.45 \%$ \\
\hline & Shanghai & Shanghai & French concession in Shanghai & 1849 & 1946 & 98 & $85.96 \%$ \\
\hline
\end{tabular}




\begin{tabular}{|c|c|c|c|c|c|c|c|}
\hline & Tianjin & Tianjin & French concession in Tianjin & 1861 & 1946 & 86 & $75.43 \%$ \\
\hline & Zhanjiang & Guangdong & French concession in Kouang-Techeou-Wan & 1989 & 1946 & 48 & $42.10 \%$ \\
\hline \multirow[t]{6}{*}{ Germany } & Amoy & Fujian & Gulangyu island & 1903 & 1945 & 43 & $37.72 \%$ \\
\hline & Beijing & Beijing & Beijing legation quarter & 1861 & 1945 & 85 & $74.56 \%$ \\
\hline & Hankou/Wuhan & Hubei & German concession in Hankou & 1895 & 1917 & 23 & $20.17 \%$ \\
\hline & Qingdao & Shandong & Kiautschou Bay leased territory & 1898 & 1914 & 17 & $14.91 \%$ \\
\hline & Shanghai & Shanghai & French concession in Shanghai & 1849 & 1946 & 98 & $85.96 \%$ \\
\hline & Tianjin & Tianjin & French concession in Tianjin & 1895 & 1917 & 23 & $20.17 \%$ \\
\hline \multirow[t]{3}{*}{ Italy } & Beijing & Beijing & Beijing legation quarter & 1861 & 1945 & 85 & $74.56 \%$ \\
\hline & Shanghai & Shanghai & Shanghai international settlement & 1863 & 1945 & 83 & $72.80 \%$ \\
\hline & Tianjin & Tianjin & Italian concession in Tianjin & 1901 & 1947 & 47 & $41.23 \%$ \\
\hline \multirow[t]{8}{*}{ Russia/Soviet Union } & Amoy & Fujian & Gulangyu island & 1903 & 1945 & 43 & $37.72 \%$ \\
\hline & Beijing & Beijing & Beijing legation quarter & 1861 & 1945 & 85 & $74.56 \%$ \\
\hline & Dalian & Liaoning & Russian concession in Dalian & 1989 & 1905 & 7 & $6.14 \%$ \\
\hline & Dalian & Liaoning & Soviet Union concession in Dalian & 1945 & 1955 & 11 & $9.65 \%$ \\
\hline & Hankou/Wuhan & Hubei & Russian concession in Hankou & 1896 & 1924 & 29 & $25.44 \%$ \\
\hline & Harbin & Heilongjiang & Chinese eastern railway, Harbin & 1896 & 1952 & 57 & $50 \%$ \\
\hline & Shanghai & Shanghai & Shanghai international settlement & 1863 & 1945 & 83 & $72.81 \%$ \\
\hline & Tianjin & Tianjin & Russian concession in Tianjin & 1900 & 1924 & 25 & $21.92 \%$ \\
\hline \multirow[t]{4}{*}{ United States } & Amoy & Fujian & Gulangyu island & 1903 & 1945 & 43 & $37.72 \%$ \\
\hline & Beijing & Beijing & Beijing legation quarter & 1861 & 1945 & 85 & $74.56 \%$ \\
\hline & Shanghai & Shanghai & Shanghai international settlement & 1863 & 1945 & 83 & $72.80 \%$ \\
\hline & Tianjin & Tianjin & American concession in Tianjin & 1860 & 1902 & 43 & $37.72 \%$ \\
\hline
\end{tabular}




\section{Table A2}

Japanese colonization in Chinese cities.

\begin{tabular}{|c|c|c|c|c|c|c|c|}
\hline Colonial power & City & Province & Event & Established & Dissolved & Duration & Intensity \\
\hline \multirow[t]{25}{*}{ Japan } & Anshan & Liaoning & Japanese Manchukuo & 1931 & 1945 & 15 & $13.15 \%$ \\
\hline & Amoy & Fujian & Partially-controlled in $2^{\text {nd }}$ Sino-Japanese War & 1937 & 1945 & 9 & $7.89 \%$ \\
\hline & Baishan & Jilin & Japanese Manchukuo & 1931 & 1945 & 15 & $13.15 \%$ \\
\hline & Baicheng & Jilin & Japanese Manchukuo & 1931 & 1945 & 15 & $13.15 \%$ \\
\hline & Benxi & Liaoning & Japanese Manchukuo & 1931 & 1945 & 15 & $13.15 \%$ \\
\hline & Beijing & Beijing & Beijing legation quarter & 1861 & 1945 & 85 & $74.56 \%$ \\
\hline & Chifeng & Inner Mongolia & Japanese Manchukuo & 1931 & 1945 & 15 & $13.15 \%$ \\
\hline & Chongqing & Chongqing & Japanese concession in Chongqing & 1897 & 1943 & 47 & $41.23 \%$ \\
\hline & Changchun & Jilin & Japanese Manchukuo & 1931 & 1945 & 15 & $13.15 \%$ \\
\hline & Chaoyang & Liaoning & Japanese Manchukuo & 1931 & 1945 & 15 & $13.15 \%$ \\
\hline & Dalian & Liaoning & Kwantung Leased Territory/South Manchuria Railway Zone & 1905 & 1945 & 41 & $35.96 \%$ \\
\hline & Dalian & Liaoning & Liaodong Peninsula & 1894 & 1895 & 2 & $1.75 \%$ \\
\hline & Dandong & Liaoning & Japanese Manchukuo & 1931 & 1945 & 15 & $13.15 \%$ \\
\hline & Fuxin & Liaoning & Japanese Manchukuo & 1931 & 1945 & 15 & $13.15 \%$ \\
\hline & Fushun & Liaoning & Japanese Manchukuo & 1931 & 1945 & 15 & $13.15 \%$ \\
\hline & Huludao & Liaoning & Japanese Manchukuo & 1931 & 1945 & 15 & $13.15 \%$ \\
\hline & Hangzhou & Zhejiang & Japanese concession in Hangzhou & 1897 & 1943 & 47 & $41.23 \%$ \\
\hline & Hegang & Heilongjiang & Japanese Manchukuo & 1931 & 1945 & 15 & $13.15 \%$ \\
\hline & Harbin & Heilongjiang & Japanese Manchukuo & 1931 & 1945 & 15 & $13.15 \%$ \\
\hline & Heihe & Heilongjiang & Japanese Manchukuo & 1931 & 1945 & 15 & $13.15 \%$ \\
\hline & Hankou/Wuhan & Hubei & Concession in Hankou & 1898 & 1943 & 46 & $40.35 \%$ \\
\hline & Jiujiang & Jiangxi & Partially-controlled in $2^{\text {nd }}$ Sino-Japanese War & 1940 & 1945 & 6 & $5.26 \%$ \\
\hline & Jilin city & Jilin & Japanese Manchukuo & 1931 & 1945 & 15 & $13.15 \%$ \\
\hline & Jiamusi & Heilongjiang & Japanese Manchukuo & 1931 & 1945 & 15 & $13.15 \%$ \\
\hline & Jinzhou & Liaoning & Japanese Manchukuo & 1931 & 1945 & 15 & $13.15 \%$ \\
\hline
\end{tabular}




\begin{tabular}{|c|c|c|c|c|c|c|}
\hline Jixi & Heilongjiang & Japanese Manchukuo & 1931 & 1945 & 15 & $13.15 \%$ \\
\hline Liaoyuan & Jilin & Japanese Manchukuo & 1931 & 1945 & 15 & $13.15 \%$ \\
\hline Mudanjiang & Heilongjiang & Japanese Manchukuo & 1931 & 1945 & 15 & $13.15 \%$ \\
\hline Panjin & Liaoning & Japanese Manchukuo & 1931 & 1945 & 15 & $13.15 \%$ \\
\hline Qiqihaer & Heilongjiang & Japanese Manchukuo & 1931 & 1945 & 15 & $13.15 \%$ \\
\hline Qingdao & Shandong & Kiautschou Bay leased territory & 1914 & 1922 & 9 & $7.89 \%$ \\
\hline Qitaihe & Heilongjiang & Japanese Manchukuo & 1931 & 1945 & 15 & $13.15 \%$ \\
\hline Shanghai & Shanghai & Fully-controlled in $2^{\text {nd }}$ Sino-Japanese War & 1937 & 1945 & 9 & $7.89 \%$ \\
\hline Siping & Jilin & Japanese Manchukuo & 1931 & 1945 & 15 & $13.15 \%$ \\
\hline Suihua & Heilongjiang & Japanese Manchukuo & 1931 & 1945 & 15 & $13.15 \%$ \\
\hline Shashi/Jingzhou & Hubei & Japanese concession in Shashi & 1898 & 1943 & 46 & $40.35 \%$ \\
\hline Suzhou & Jiangsu & Japanese concession in Suzhou & 1897 & 1943 & 47 & $41.23 \%$ \\
\hline Songyuan & Jilin & Japanese Manchukuo & 1931 & 1945 & 15 & $13.15 \%$ \\
\hline Shuangyashan & Heilongjiang & Japanese Manchukuo & 1931 & 1945 & 15 & $13.15 \%$ \\
\hline Shenyang & Liaoning & Japanese Manchukuo & 1931 & 1945 & 15 & $13.15 \%$ \\
\hline Tianjin & Tianjin & Japanese concession in Tianjin & 1898 & 1943 & 46 & $40.35 \%$ \\
\hline Tieling & Liaoning & Japanese Manchukuo & 1931 & 1945 & 15 & $13.15 \%$ \\
\hline Tonghua & Jilin & Japanese Manchukuo & 1931 & 1945 & 15 & $13.15 \%$ \\
\hline Yingkou & Liaoning & Japanese Manchukuo & 1931 & 1945 & 15 & $13.15 \%$ \\
\hline Yichun & Heilongjiang & Japanese Manchukuo & 1931 & 1945 & 15 & $13.15 \%$ \\
\hline Weihai & Shandong & Japanese concession in Weihai & 1895 & 1898 & 4 & $3.51 \%$ \\
\hline
\end{tabular}

